\title{
SEA SURFACE TEMPERATURE (SST) AND RAINFALL EROSIVITY IN THE UPPER GRANDE RIVER BASIN, SOUTHEAST BRAZIL
}

\author{
Temperatura da superfície do mar (TSM) e erosividade da chuva na \\ bacia hidrográfica do Alto Rio Grande, sudeste do Brasil
}

\author{
Carlos Rogério de Mello ${ }^{1}$, Lloyd Darrell Norton², Nilton Curi³ ${ }^{3}$, Silvia Nazaré Monteiro Yanagi ${ }^{4}$
}

\begin{abstract}
Relationships between regional climates and oceanic and atmospheric anomalies are important in understanding the rainfall regime of a given region. This work aimed to analyze rainfall erosivity in the Upper Grande River Basin, Southern Minas Gerais State, Brazil; namely the two most representative environments, the Mantiqueira Range (MR) and the Plateau of Campos das Vertentes (PCV). These areas can be affected by the El Niño Southern Oscillation (ENSO) phenomena, which can be evaluated by indicators such as Sea Surface Temperature (SST) for the Niño 3.4 Region. Rainfall erosivity was calculated for individual rainfall events from January, 2006 to December, 2010. Pearson's coefficient of correlation was used to evaluate the relationships between rainfall variables and SST. The coefficients of correlation were significant for both sub-regions. Correlations between the rainfall variables and negative oscillations of SST were also significant, especially in the MR sub-region, however, the Person's coefficients were lower than those obtained for the SST positive oscillations. These results demonstrate that El-Niño phenomenon can be considered an important factor in the intense rainfall behavior of the Upper Grande River Basin.
\end{abstract}

Index terms: Soil erosion, El-Niño, La-Niña, Grande River basin.

\section{RESUMO}

Relações entre o clima regional e as anomalias oceânicas e atmosféricas consistem de importantes ferramentas para o entendimento do regime de chuvas intensas em uma dada região. Neste trabalho, objetivou-se analisar a erosividade da chuva na bacia hidrográfica do Alto Rio Grande, sul de Minas Gerais. O estudo considerou as duas sub-regiões mais representativas da mesma, sendo a Serra da Mantiqueira (SM) e o Planalto Campos das Vertentes (PCV). Essas áreas podem ser afetadas pelos fenômenos associados ao El Niño Oscilação Sul (ENSO), o qual pode ser avaliado como função da Temperatura da Superfície do Mar (TSM) para a região do Niño 3.4. A erosividade da chuva foi calculada para cada evento individual de chuva entre janeiro/2006 e dezembro/2010. O coeficiente de correlação de Pearson foi usado para avaliar as possíveis relações entre as variáveis associadas às chuvas erosivas e à TSM. Os coeficientes de correlação foram significativos para ambas as sub-regiões. As correlações entre as variáveis estudadas e as oscilações negativas da TSM também foram significativas, especialmente para a sub-região SM, contudo, os coeficientes foram menores do que aqueles obtidos para oscilações positivas. Os resultados demonstram que o fenômeno El-Niño pode ser mais importante para o comportamento de chuvas intensas na cabeceira da bacia do rio Grande.

Termos para indexação: Erosão do solo, El-Niño, La-Niña, bacia do Rio Grande.

\section{(Received in february 9, 2012 and approved in february 28, 2012)}

\section{INTRODUCTION}

Soil erosion is a major environmental problem in many countries around the world. Its origin is associated with several factors which can be classified as active or passive. The active factor is controlled by spatial and temporal rainfall distribution and is known as rainfall erosivity which is defined as the eroding power of raindrop impact (rain splash).

The South Atlantic Convergence Zone (SACZ), convective rainfall events, frontal systems (cold fronts) and cyclones help to explain the rainfall regimes in Southeast Brazil (REBOIA et al., 2010). These general climatic aspects cause high temporal rainfall variability and are characterized in a given year by an extremely rainy season or by highly concentrated rainfall within a few months. However, there are other climatic aspects that can also influence the rainfall regime, such as anomalies linked to the Equatorial Pacific Ocean. The El-Niño Southern Oscillation (ENSO) is one of the most important oceanic anomalies which influence climatic aspects on a large regional scale in a given year.

There are some meteorological indicators that can be associated to ENSO, highlighting the Sea Surface Temperature (SST) in the Equatorial Pacific region. This ENSO's indicator can significantly influence rainfall distribution around the world (ROPELEWSKI; HALPERT, 1989; DE PAULA et al., 2010) and consequentially, rainfall erosivity as well.

\footnotetext{
1Universidade Federal de Lavras/UFLA - Departamento de Engenharia/DEG - Cx. P. 3037 - 37200-000 - Lavras - MG - Brasil - crmello@deg.ufla.br ${ }^{2}$ Purdue University - USDA/ARS - National Soil Erosion Research Laboratory - West Lafayette - IN - USA

${ }^{3}$ Universidade Federal de Lavras/UFLA - Departamento de Ciência do Solo/DCS - Lavras - MG - Brasil

${ }^{4}$ Universidade Federal de Lavras/UFLA - Departamento de Engenharia/DEG - Lavras - MG - Brasil
} 
Current scientific investigations have searched to establish statistical relationships between ENSO indicators and regional (or local) climatic characteristics. Nevertheless, these studies have been mainly associated with monthly rainfall and discharges from large basins (CHANDIMALA; ZUBAIR, 2007; LÜ et al., 2011; WHITAKER et al., 2011) and only a few have taken care to investigate how the rainfall erosivity can be affected by ENSO's (SIMPSON et al., 1993; D‘ODORICO et al., 2001).

The ENSO's variations have been well studied in recent years, and their behavior reasonably predicable. According to Whitaker et al. (2011), some ENSO's indices can be forecasted up to 2-year ahead. The search for relationships between ENSO indicators and rainfall behavior for a given region has been carried out with the objective of evaluating their potential in forecasting rainfall indicators (D‘ODORICO et al., 2001; ROMERO et al., 2007).

The Upper Grande River Basin (UGRB) is located in southern Minas Gerais, Brazil, and corresponds to a headwater region of the Grande River Basin. The UGRB contains two specifically environments: the Mantiqueira Range (MR) and the Plateau of Campos das Vertentes (PCV). The first is responsible for the Grande River springs and presents elevations above sea level (asl) greater than 2,300 $\mathrm{m}$, having mountainous and strong undulated relief. The PCV environment can be characterized by rangelands associated with elevations between $800-1100 \mathrm{~m}$ asl. In both sub-regions, there is no sufficient rainfall monitoring data for evaluating rainfall erosivity; only from 2006, with support from CEMIG/ANEEL, has a more precise temporal rainfall monitoring system been installed for this purpose. Because of this, there are serious problems with constructing long-term pluviographical data sets in a region indispensable for evaluating individual rainfall erosivity events.

Based on the context described above, the objective of this work was to investigate the rainfall erosivity behavior of, and analyze statistical relationships between, rainfall erosive variables and SST indices for the UGRB, Southern Minas Gerais State, Brazil.

\section{MATERIALS AND METHODS}

\section{Geographical location and characteristics of the Upper Grande River Basin (UGRB)}

The Upper Grande River Basin (UGRB) is located in the south of the state of Minas Gerais, draining approximately $9,000 \mathrm{~km}^{2}$ and is the headwater region of the Grande River Basin $\left(145,000 \mathrm{~km}^{2}\right)$. In the UGRB, there are two distinct sub-regions, which are: the Mantiqueira Range (MR) and the Plateau of Campos das Vertentes (PCV). The geographical location of the UGRB is presented in Figure 1, as well as the locations of the automatic meteorological stations used in this study.

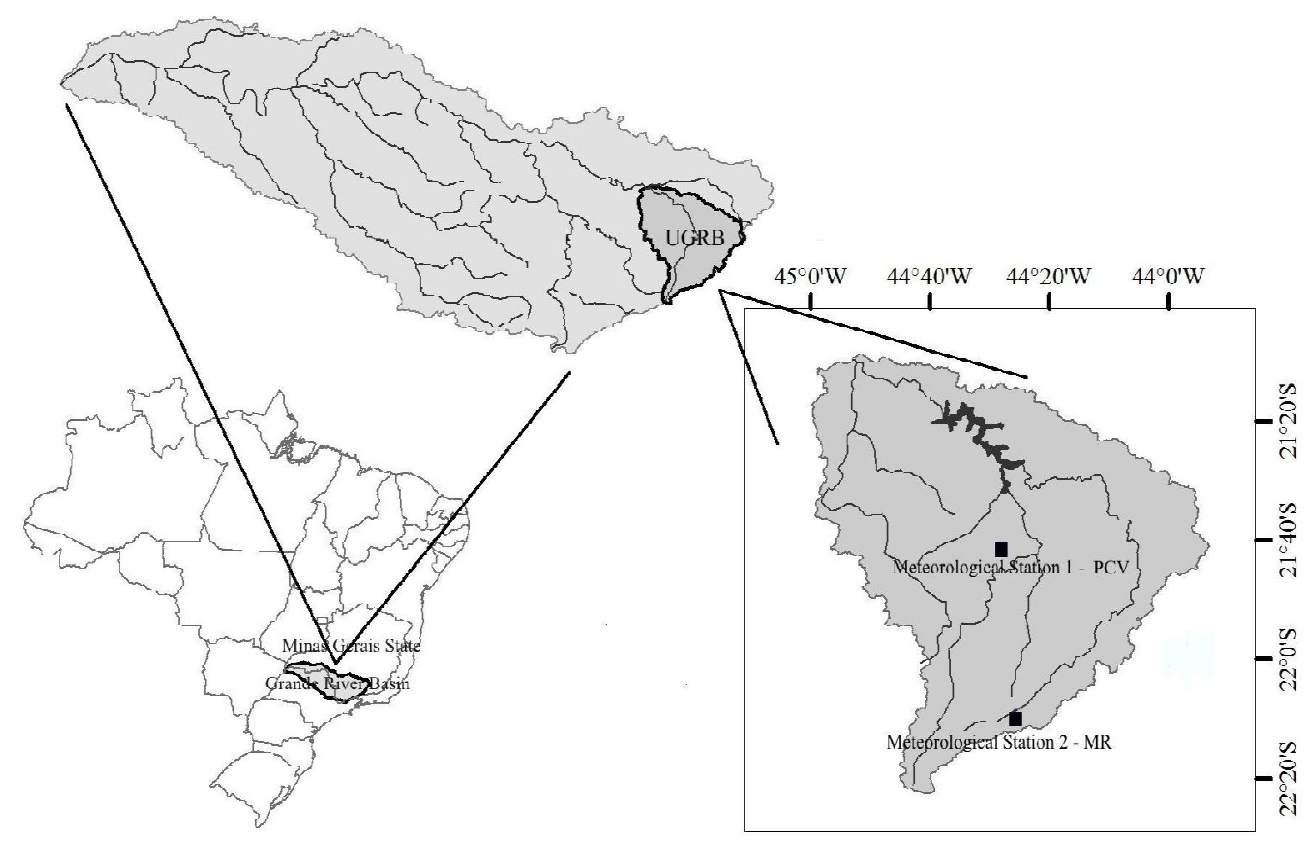

Figure 1 - The geographic location of the UGRB and the location of the meteorological automatic stations used in this study. 
According to Sparovek et al. (2007), the MR subregion has a climatic type Cwb, by Köppen Procedure Classification, with mean annual precipitation of about $2,100 \mathrm{~mm}$ and a mean annual temperature of around $15^{\circ}$ C. The PCV sub-region includes both $\mathrm{Cwb}$ and $\mathrm{Cwa}$ climatic types, with mean annual precipitation of about $1,500 \mathrm{~mm}$ and mean annual temperature around $18^{\circ} \mathrm{C}$. July and January are the coldest and warmest months, respectively, in both sub-regions. For both climatic types, the summer is characterized as rainy, with moderate temperatures, including almost $80 \%$ of the total amount of rainfall; the winter is cool and much drier than the summer.

\section{Relationships between SST indices and rainfall erosive variables}

The rainfall data sets used in this study came from two Automatic Meteorological Stations, assembled in representative watersheds in each sub-region (see Figure 1) and have been recording values every 15 minutes, since 2006. In this study, 434 and 336 rainfall events were evaluated for, respectively, MR and PCV sub-regions from the period from January 2006 to December 2010. Pluviometric data sets are available for the region from the National Water Agency (ANA), however, these are not sufficient for performing studies related to individual rainfall erosive events, as they are recorded in daily intervals. For this study, a given event was considered feasible when at least $3 \mathrm{~mm}$ rainfall depth had occurred separated by up to 6 hours. We used this criterion because $3 \mathrm{~mm}$ or less of precipitation does not promote significant changes in the soil water budget (PÉRON; CASTRO NETO, 1986). To evaluate whether a given rainfall event can be considered as erosive, two criteria were considered: kinetic energy of rainfall greater than 3.6 $\mathrm{MJ} \mathrm{ha}^{-1}$ or a rainfall depth greater than $12.5 \mathrm{~mm}$ over 10 minutes (CATARI et al., 2011).

The rainfall kinetic energy was calculated using the equation recommended by Brown and Foster (1987):

$$
E c=0.29 \cdot[1-0.72 \cdot \exp (-0.05 \cdot I)]
$$

where Ec is the rainfall kinetic energy $\left(\mathrm{MJ} \mathrm{ha}^{-1} \mathrm{~mm}^{-1}\right)$ and I is the rainfall intensity $\left(\mathrm{mm} \mathrm{h}^{-1}\right)$. These authors suggest this equation instead of that from Wischmeier and Smith (1978) because it was adjusted using a better data base. The total kinetic energy of rainfall and rainfall erosivity $\left(\left(\mathrm{MJ} \mathrm{mm}(\text { ha h })^{-1}\right)\right)$ were obtained according to Wischmeier and Smith (1978).
The rainfall variables used to determine Pearson's coefficient of correlation were: Rainfall erosivity $\left(\mathrm{EI}_{30}\right)$; depth of rainfall $(\mathrm{P})$; rainfall erosive pattern; number of rainfall events (NRE); and number of rainfall erosive events (NEE). In terms of the rainfall erosive pattern, the following procedure was used: the duration of rainfall was divided into three equal parts (33\% of the duration for each part); if the peak of intensity occurs in the first part (from 0 to $33 \%$ of duration), the rainfall is classified as "early pattern" (ep); in the second part (from 33 to $66 \%$ of duration), "intermediate pattern" (ip); and in third part (from 66 to $100 \%$ of duration), "late pattern" (lp). Monthly Sea Surface Temperature (SST) data set was retrieved from Climate Prediction Center of the US National Oceanic and Atmospheric Administration (CPC, NOAA), from the website at www.cpc.noaa.gov/data/indices/soi. The SST values are associated to El Niño 3.4, whose coordinates are $5^{\circ} \mathrm{N}-5^{\circ} \mathrm{S} ; 120^{\circ} \mathrm{W}-170^{\circ} \mathrm{W}$, as this El Niño region exerts a greater influence on climatic conditions in Brazil than others (DE PAULA et al., 2010). Figure 2 shows the SST values from January 2006 to December 2010, and it is possible to identify ENSO phases throughout the period evaluated.

Pearson's coefficient of correlation and "Studentt" significance tests were used for evaluating the existence of the relationships between monthly rainfall erosive variables and SST indices. The correlation study was conducted taking into account positive and negative monthly oscillations, meaning trends in El-Niño and La-Niña episodes, respectively. These procedures were also used by Chandimala and Zubair (2007) and Lü et al. (2011) to evaluate the relationships between rainfall and discharge in headwater region of the Yellow River and in Sri-Lanka. D'Odorico et al. (2001) also studied the possible relationships between rainfall erosivity and SST indices for the Southwest US based on this procedure.

\section{RESULTS AND DISCUSSION}

\section{Rainfall erosivity behavior in the UGRB between 2006 and 2010}

Table 1 presents annual values of rainfall erosivity $\left(\mathrm{EI}_{30}\right)$ and rainfall depth $(\mathrm{P})$ for the MR and PCV subregions, as well as mean annual values for SST indices during the period of monitoring (2006-2010). A substantial intra-annual variability of $\mathrm{P}$ can be verified due to climatic characteristics of southern Minas Gerais, which has a high concentration of rainfall in the summer (Reboita et al., 2010). 
Using Foster's rainfall erosivity classification (Foster et al., 1981), the MR sub-region can be classified as "very strong" due to mean annual erosivity greater than 9,810 MJ mm (ha h) $)^{-1}$ year $^{-1}$. It is important to highlight that only one year (2007) had an $\mathrm{EI}_{30}$ lesser than the threshold used for distinguishing a "very strong" classification. Gonçalves et al. (2006) and Montebeller et al. (2007) found mean rainfall erosivity values greater than 10,000 and $12,000 \mathrm{MJ} \mathrm{mm}$ (ha h) ${ }^{-1}$ year $^{-1}$ for the Atlantic Range region of Rio de Janeiro State which neighbors the MR subregion. These results demonstrate that the values found for the MR sub-region are close to the values obtained by other studies, although a shorter term rainfall data set was used here.
For the PCV sub-region, the mean annual rainfall

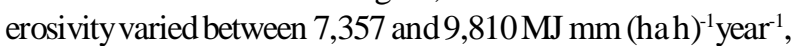
thus allowing it to be classified as a "strong" rainfall erosivity region. Nevertheless, it is possible to observe, in Table 1, an intra-annual variability greater than for the MR sub-region, with values varying from 3,728 to 10,199 MJ $\mathrm{mm}$ (ha h) $)^{-1}$ year $^{-1}$, generating classifications from "medium" to "very strong" rainfall erosivity. According to Val et al. (1986), for the Lavras region, (located in the north-west, approximately $120 \mathrm{~km}$ from Meteorological Station $1-\mathrm{PCV}$ (Figure 1)), the mean annual rainfall erosivity was 6,837 MJ $\mathrm{mm}$ (ha h) $)^{-1}$ year $^{-1}$. Based on this result, the values found in this study are in adequate agreement with the literature and are representative of this sub-region.

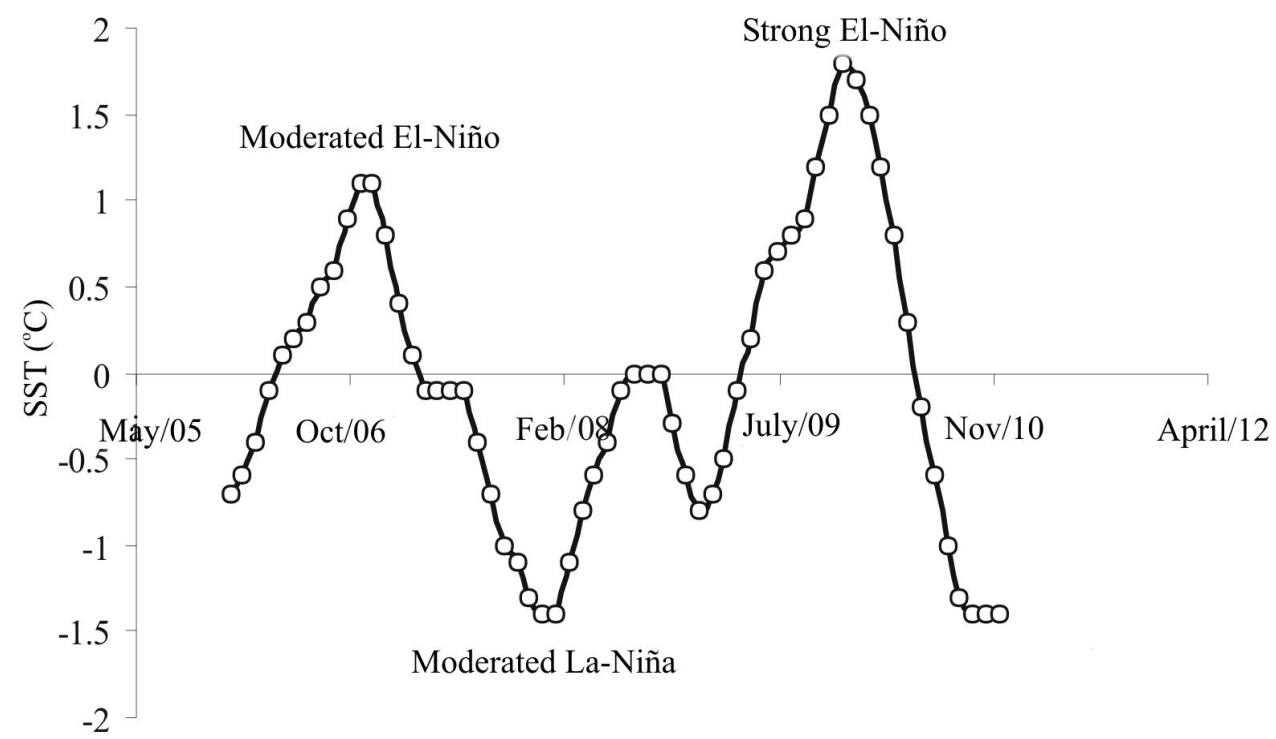

Figure 2 - SST indices for Niño 3.4 between January 2006 and December 2010 (CPC, NOAA).

Table 1 - Annual rainfall erosivity $\left(\mathrm{EI}_{30}\right)$ and corresponded rainfall depth $(\mathrm{P})$ for the MR and PCV sub-regions (UGRB), Southern of Minas Gerais State.

\begin{tabular}{lccccc}
\hline & \multicolumn{2}{c}{ MR } & \multicolumn{2}{c}{ PCV } \\
\hline Year & Mean SST $\left({ }^{\circ} \mathrm{C}\right)$ & $\begin{array}{c}\mathrm{EI}_{30} \\
\left(\mathrm{MJ} \mathrm{mm}(\mathrm{ha} \mathrm{h})^{-1}\right)\end{array}$ & $\begin{array}{c}\mathrm{P} \\
(\mathrm{mm})\end{array}$ & $\begin{array}{c}\mathrm{EI}_{30} \\
\left.(\mathrm{MJ} \mathrm{mm} \mathrm{(ha} \mathrm{h})^{-1}\right)\end{array}$ & $\begin{array}{c}\mathrm{P} \\
(\mathrm{mm})\end{array}$ \\
\hline 2006 & 0.250 & 14588.61 & 2047 & 5428.39 & 1310 \\
2007 & -0.300 & 7940.16 & 1841 & 3728.25 & 1204 \\
2008 & -0.558 & 10330.28 & 2756 & 10199.43 & 1872 \\
2009 & 0.467 & 12585.20 & 2536 & 9560.82 & 1895 \\
2010 & -0.150 & 12899.67 & 2140 & 9647.89 & 1776 \\
\hline & Mean & 11668.78 & 2264 & 7712.96 & 1611 \\
& C.V. & 0.221 & 0.165 & 0.380 & 0.204 \\
\hline
\end{tabular}

Ciênc. agrotec., Lavras, v. 36, n. 1, p. 53-59, jan./fev., 2012 


\section{Relationships between SST indices and rainfall erosive variables}

Pearson's coefficients of correlation and the "Student- $\mathrm{t}$ " statistical test are presented in Table 2 for variables related to rainfall erosive events. Previous studies in Brazil relating a statistical coefficient such as Pearson's coefficient between annual rainfall erosivity and ENSO indicators are very rare. Lü et al. (2011), in studying monthly rainfall and mean discharge in the headwater region of the Yellow River, China, adopted monthly values of SST as ENSO indicators and found significant correlations. D'Odorico et al. (2001), in the south-west US, found a significant coefficient of correlation between SST $>0$ and rainfall erosivity, using a similar methodology to Lü et al. (2011).

A gradual increase in SST throughout 2006 can be observed, culminating in a moderate El-Niño, thus producing an annual positive value for SST, however, close to that of a neutral year (Table 1). Nevertheless, the months from January to March 2006 had below average rainfall and the monthly values of SST are negative, indicating that there was negative correlation between SST and rainfall on these months which would have more weight on the annual rainfall. Using the same approach, the increase in SST values can be related to the rainfall value recorded in both sub-regions in January 2007. For the PCV, $483 \mathrm{~mm}$ was recorded which corresponded to $40.1 \%$ of annual value for that year. In the MR sub-region, $632 \mathrm{~mm}$ was recorded, corresponding to $34.3 \%$ of the annual value. However, throughout 2007, an important decrease was recorded in the SST value, characterizing a moderate La-Niña for the 2007-2008 summer; in that year a rainfall value considerably below the average was recorded. All of these aspects indicate that there is a monthly relationship between rainfall erosive characteristics and SST, helping to justify the coefficients of correlation presented in Table 2.

Regarding the correlations between negative SST and rainfall erosive variables, it is possible to observe that the correlations were significant and negative, meaning that during SST negative oscillation (La-Niña episodes), there was a reduced number of rainfall events, rainfall depth and rainfall erosive power. Pearson's coefficients were more significant for the MR, so the number of variables were highly significant which means the La-Niña episodes have greater influence on MR rainfall behavior than on PCV. In addition, monthly values of $\mathrm{EI}_{30}$ were not significant in PCV under SST negative.

Table 2 - Pearson's correlation coefficients between monthly SST indices and rainfall erosive variables in the MR and PCV sub-regions (UGRB), between 2006 and 2010.

\begin{tabular}{|c|c|c|c|c|}
\hline SST $<0$ correlations & $\mathrm{r}(\mathrm{MR})$ & $|t|_{\text {value }}$ & $\mathrm{r}(\mathrm{PCV})$ & $|\mathrm{t}|_{\text {value }}$ \\
\hline $\mathrm{EI}_{30}$ & $-0.402 *$ & 0.0203 & $-0.267^{\mathrm{ns}}$ & 0.134 \\
\hline Number of Rainfall Events (NRE) & $-0.503 * *$ & 0.0029 & $-0.395^{*}$ & 0.0227 \\
\hline Number of Erosive Events (NEE) & $-0.472 *$ & 0.0221 & $-0.506^{* *}$ & 0.0026 \\
\hline Rainfall Depth $(\mathrm{P})$ & $-0.545 * *$ & 0.0011 & $-0.473^{*}$ & 0.0305 \\
\hline Early Rainfall Pattern (ep) & $-0.386^{*}$ & 0.0448 & $-0.208^{\mathrm{ns}}$ & 0.245 \\
\hline Late Rainfall Pattern (lp) & $-0.292^{\mathrm{ns}}$ & 0.119 & $-0.223^{\mathrm{ns}}$ & 0.213 \\
\hline Intermediate Rainfall Pattern (ip) & $0.061^{\mathrm{ns}}$ & 0.606 & $-0.262^{\mathrm{ns}}$ & 0.139 \\
\hline $\mathrm{SST}>0$ correlations & $\mathrm{r}(\mathrm{MR})$ & $|\mathrm{t}|_{\text {value }}$ & $\mathrm{r}(\mathrm{PCV})$ & $|t|_{\text {value }}$ \\
\hline $\mathrm{EI}_{30}$ & $0.699 * *$ & 0.00014 & $0.721 * *$ & 0.00007 \\
\hline Number of Rainfall Events (NRE) & $0.664 * *$ & 0.00041 & $0.716^{* *}$ & 0.00008 \\
\hline Number of Erosive Events (NEE) & $0.675^{* *}$ & 0.00012 & $0.704 * *$ & 0.0003 \\
\hline Rainfall Depth $(\mathrm{P})$ & $0.668^{* *}$ & 0.00036 & $0.703 * *$ & 0.00013 \\
\hline Early Rainfall Pattern (ep) & $0.478 *$ & 0.0182 & $0.738 * *$ & 0.00004 \\
\hline Late Rainfall Pattern (lp) & $0.072^{\mathrm{ns}}$ & 0.737 & $0.306^{\mathrm{ns}}$ & 0.146 \\
\hline Intermediate Rainfall Pattern (ip) & $-0.179^{\mathrm{ns}}$ & 0.403 & $0.297^{\mathrm{ns}}$ & 0.158 \\
\hline
\end{tabular}


In context of the relationships between rainfall erosive variables and positive oscillations of SST, which indicate a trend toward El-Niño episodes, positive Pearson's coefficients can be observed which are more significant than the coefficients obtained for relationships with negative oscillations of SST. These results mean that when SST indicates a positive oscillation, meaning trend toward El-Niño episodes, in both sub-regions, there is an increase in rainfall depth, rainfall erosivity, number of rainfall events and number of rainfall erosive events. As a result, more erosive rainfall events are expected and consequently more serious environmental problems will tend to occur than during the seasons under negative oscillations of SST in the UGRB. These results are consistent with those of Haylock et al. (2006) which concluded that rainfall behavior in southeastern Brazil is more connected to ElNiño episodes. Also, Carvalho et al. (2002), studying the frequency of extreme rainfall in Southeastern Brazil, concluded that there were more extreme events during ElNiño conditions than La-Niña.

For the rainfall erosivity variables tested, Pearson's coefficients obtained for the PCV sub-region were greater than those obtained for MR sub-region when positive oscillations of SST were found. This behavior is possibly associated with the orographic effects which are much more significant for the MR sub-region. According to Nel et al. (2010), who studied the rainfall erosivity behavior in a mountainous region of South Africa, altitude can promote better atmospheric conditions for cloud formation due to a lower vapor saturation pressure. These local and regional meteorological aspects can mitigate the influence of remote anomalies. This aspect was also commented by Grimm (2003) in a study of the impact of El-Niño on summer rainfall in Brazil.

Notwithstanding the short period of rainfall evaluated in this study (due to the absence of an adequate rainfall data base for this region) important relationships between rainfall erosive variables and SST were identified. These relationships were mainly significant for positive oscillations of SST, meaning the greater the SST, the greater the rainfall erosivity.

\section{CONCLUSION}

The MR sub-region has "very strong" rainfall erosivity potential and the PCV sub-region, a "strong" potential. Both sub-regions present strong intra-annual variability of rainfall erosivity, which is accentuated by ENSO oscillations. Pearson's correlation coefficients were highly significant between monthly rainfall erosive variables and SST positive oscillations in the UGRB, stressing the PCV sub-region, which indicates that El-Niño episodes can produce a significant impact on rainfall erosivity behavior. Correlations with negative SST oscillations were also significant for the UGRB, especially for the MR sub-region, but lesser than those obtained when positive SST oscillations occurred.

\section{REFERENCES}

BROWN, L.C.; FOSTER, G.R. Storm erosivity using idealized intensity distributions. Transactions of the ASABE, St. Joseph, v.30, n. 2, p. 379-386, 1987.

CARVALHO, L.M.V.; JONES, C.; LIEBMANN, B. Extreme precipitation events in southeastern South America and large-scale convective patterns in the South Atlantic convergence zone. Journal of Climate, Boston, v.15, n. 17, p. 2377-2394, 2002.

CATARI, G.; LATRON, J.; GALLART, F. Assessing the sources of uncertainty associated with the calculation of rainfall kinetic energy and erosivity - application to the Upper Llobregat Basin, NE Spain. Hydrology and Earth System Sciences Discussions, Göttingen, v. 15, p.679$688,2011$.

CHANDIMALA, J.; ZUBAIR, L. Predictability of stream flow and rainfall based on ENSO for water resources management in Sri Lanka. Journal of Hydrology, Amsterdan, v. 335, n. 3-4, p. 303-312, 2007.

D'ODORICO, P.; YOO, J.; OVER, T. M. An assessment of ENSO-induced patterns of rainfall erosivity in the southwestern United States. Journal of Climate, Boston, v.14, n. 21 p.4230-4242, 2001.

DE PAULA, G.M. et al. Influência do fenômeno El-Niño na erosividade das chuvas na região de Santa Maria (RS). Revista Brasileira de Ciência do Solo, Viçosa, v. 34, p. 1315-1323, 2010.

FOSTER, G.R. et al. Conversion of the universal soil loss equation to SI metric units. Journal of Soil and Water Conservation, Ankeny, v.36, n. 6, p. 355-359, 1981.

GONÇALVES, F.A. et al. Índices e espacialização da erosividade das chuvas para o Estado do Rio de Janeiro. Revista Brasileira de Engenharia Agrícola e Ambiental, Campina Grande, v.10, n. 2, p. 269-276, 2006. 
GRIMM, A. M. The El-Niño impact on the summer Monsoon in Brazil: regional processes versus remote influences. Journal of Climate, Boston, v.16, n. 2, p. 263-280, 2003.

HAYLOCK, M.R. et al. Trends in total and extreme South American Rainfall in 1960-2000 and links with sea surface temperature. Journal of Climate, Boston, v.19, n. 8, p.1490-1512, 2006.

LÜ, A. et al. El-Niño-Southern Oscillation and water resources in the headwaters region of the Yellow River: links and potential for forecasting. Hydrology and Earth System SciencesDiscussions, Göttingen, v.15, n. 4, p.1273-1281, 2011.

MONTEBELLER, C.A. et al Variabilidade espacial do potencial erosivo das chuvas no Estado do Rio de Janeiro. Engenharia Agrícola, Jaboticabal, v. 27, n. 2, p. 426-435, 2007.

NEL, W.; REYNHARDT, D.A.; SUMNER, P.D. Effect of altitude on erosive characteristics of concurrent rainfall events in the northern KwaZulu-Natal Drakensberg. Water SA, Gezina, v.36, n. 4, p.509-512, 2010.

PERÓN, A.J.; CASTRO NETO, P. Probabilidade de ocorrência de veranicos na região de Lavras, Minas Gerais. Ciência e Prática, Lavras, v. 10, n. 3, p. 282-290, 1986.

REBOITA, M. S. et al. Regimes de precipitação na América do Sul: uma revisão bibliográfica. Revista Brasileira de Meteorologia, São José dos Campos, v. 25, n. 2, p.185-204, 2010.
ROMERO, C. C.; BAIGORRIA, GA.; STROOSNIJDER, L. Changes of erosive rainfall for El-Niño and La-Niña years in the northern Andean highlands of Peru. Climatic Change, New York, v. 85, n. 3-4, p. 343-356, 2007.

ROPELEWSKI, C.F.; HALPERT, M.S. Precipitation patterns associated with high index phases of Southern Oscillation. Journal of Climate, Boston, v. 2, n. 3, p. 268284, 1989.

SIMPSON, H.J. et al. Annual river discharge in southeastern Australia related to El-Niño Southern Oscillation forecasts of sea surface temperatures. Water Resources Research, Washington, v.29, n. 11, p.36713680, 1993.

SPAROVEK, G.; VAN LIER, Q. J.; DOURADO NETO, D. Computer assisted Koeppen climate classification: a case study for Brazil. International Journal of Climatology, Hoboken, v. 27, n.2, p. 257-266, 2007.

VAL, L.A. et al. Erosividade das chuvas em Lavras, MG. Ciência e Prática, Lavras, v.10, n. 2, p. 199-209, 1986.

WHITAKER, D.W.; WASIMI, S.A.; ISLAM, S. The ElNiño Southern Oscillation and long-range forecasting of flows in the Ganges. International Journal of Climatology, Hoboken, v. 21, n. 1, p. 77-87, 2011.

WISCHMEIER, W.H.; SMITH, D.D. Predicting rainfall erosion losses: a guide to conservation planning. Washington: USDA Agricultural Handbook, 1978. 58p. 